\title{
Efficacy of Pre and Post Emergence Herbicides against Weed Flora in Onion (Allium cepa L.)
}

\author{
Akanksha Thakare, S. U. Kakade*, J. P. Deshmukh, N. D. Parlawar and S. S. Thakare
}

All India Coordinated Research Project on Weed Management, Department of Agronomy, Dr.Panjabrao Deshmukh Krishi Vidyapeeth, Akola-444104(M.S), India

*Corresponding author

\begin{abstract}
A B S T R A C T
A field investigation entitled efficacy of pre and post emergence herbicides against weed flora in onion (Allium cepa L.) was carried out at AICRP on weed management field of Agronomy Department, Dr. Panjabrao Deshmukh Krishi Vidyapeeth, Akola during the Rabi season of 2018-19. The investigation was carried out to

Keywords evaluate the efficacy of different pre and post emergence herbicides against weed flora, as well as to study the phytotoxic effect on the crop, yield of onion and to study the economics of different method of weed control in onion. The experiment was laid out in randomized block design with nine treatment replicated thrice. The treatment comprised of different pre-emergence, post-emergence herbicides in different doses and were compared with cultural method. The soil of experimental field was fairly uniform and leveled and characterized as clayey in texture, having slightly alkaline reaction with $\mathrm{pH}(7.7)$ low organic carbon status $(0.41 \%)$, low nitrogen content $\left(197.21 \mathrm{~kg} \mathrm{ha}^{-1}\right)$, medium available phosphorus $\left(18.76 \mathrm{~kg} \mathrm{ha}^{-1}\right)$ and rich in available potassium (366.49 kg ha-1). Onion (Variety- Akola Safed) was transplanted on $14^{\text {th }}$ December 2018 at $20 \times 10 \mathrm{~cm}$ spacing with fertilizer dose of 100:50:50 NPK kg ha ${ }^{-1}$. The results revealed that among the various treatments under study weed free recorded significantly higher values of major parameters wheareas, in the herbicidal treatments, the maximum yield attributes were recorded with application of pendimethalin $24 \%+$ oxyfluorfen $4 \% \mathrm{ZE} @ 600+102.5 \mathrm{~g}$ a.i./ha which was at par with treatment Oxyfluorfen 23.5\% EC@ $200 \mathrm{~g}$ a.i./ha. Among the herbicidal treatment, reduction in weed population, weed dry matter, higher weed control efficiency $(85.86 \%)$ and lowest weed index $(4.29 \%)$ was found with pendimethalin $24 \%$ + oxyfluorfen $4 \%$ ZE @ $600+102.5 \mathrm{~g}$ a.i./ha and higher weed index in weedy check (54.33). Pendimethalin 24\% + oxyfluorfen 4\% ZE @600+102.5 g a.i./ha was found most economical with maximum value of GMR (188290 Rs ha ${ }^{-1}$, NMR ( $126520 \mathrm{Rs} \mathrm{ha}^{-1}$ ) and B: C ratio (3.04). The net return per hectare was more under cultural practice i.e. two hand weeding at 25 and 45 DAT but the difference was not much when compared to effective pre emergence herbicide (Pendimethalin $24 \%+$ oxyfluorfen $4 \%$ ZE @600+102.5 g a.i./ha).
\end{abstract}

\section{Introduction}

Onion is one of the most important commercial bulbous vegetable crop belonging to family Amaryllidaceae grown from ancient times having more demand in domestic market as well as in export market due to its ability to fetch handsome foreign exchange. India ranks second in area and production of onion in world after china. Major contributing states in onion production are Maharashtra, Karnataka, Madhya Pradesh, Bihar and Gujrat. In India onion occupies about 1.20 million hectare area having 19.40 million metric tonnes of production and average productivity of 16.13 metric tonnes $\mathrm{ha}^{-1}$.

In Maharashtra, it is grown over an area of 0.9 million hectare with total production of 2.06 million metric tonnes with average 
productivity of 16.51 metric tonnes $\mathrm{ha}^{-1}$ (Anonymous, 2017). Among various constraints faced by onion growing farmer community, weed pose serious problem in onion cultivation which reduces bulb yield production to the extent of 40-80\% (Vishnu et al., 2014). The conventional or cultural method of weed control i.e. hoeing, hand weeding is no doubt beneficial but it is cumbersome, time consuming, labour consuming and uneconomical under certain condition due to higher labour wages. Due to industrial development, most of the labours migrate to the urban area and hence there is scarcity of labour. Moreover inherent characteristics of onions such as short stature, non- branching habitat, spare foliage, close planting of transplant, shallow root system of seedling, extremely slow initial growth frequent irrigation provide congenial condition for weed growth and conventional method weed control quite ineffective against uprooting of weed (Ibrahim et al., 2011). Under such circumstances application of herbicides offer aappropriate suitable and reliable option of weed control (Uygur et al., 2010). Keeping this factor in view, the present investigation was planned with a objective to study the efficacy of pre and post emergence herbicide against weed flora in onion, phytotoxicity on crop and profitability in onion.

\section{Materials and Methods}

The present field experiment was conducted during Rabi season of the year 2018-19 at the research farm of AICRP-Weed Management, Dr.Panjabrao Deshmukh Krishi Vidyapeeth, Akola (M.S.) in Randomized Block Design with three replication having nine different treatments of weed management including Pendimethalin 24\% + Oxyfluorfen $4 \%$ ZE @ 480+82 g a.i./ha PE $\left(\mathrm{T}_{1}\right)$, Pendimethalin 24\% + Oxyfluorfen 4\% ZE @ 541.80+92.56 g a.i./ha PE $\left(\mathrm{T}_{2}\right)$, Pendimethalin $24 \%+$
Oxyfluorfen 4\% ZE @600+102.5 g a.i./ha PE $\left(\mathrm{T}_{3}\right)$, Pendimethalin 24\% + Oxyfluorfen $4 \%$ ZE@1083.60+185.12 g a.i./ha PE $\left(\mathrm{T}_{4}\right)$ are the herbicide with combine (pre-mix) formulation with different concentration of active ingredient, Pendimethalin 38.7\% CS@ $677.25 \mathrm{~g}$ a.i./ha PE $\left(\mathrm{T}_{5}\right)$, Oxyfluorfen $23.5 \%$ EC@ 200 g a.i./ha PE ( $\left.\mathrm{T}_{6}\right)$, Quizalofop ethyl 5\% EC@ 50 g a.i./ha $\operatorname{PoE}\left(\mathrm{T}_{7}\right), 2$ Hand weeding $25 \& 45$ DAT $\left(\mathrm{T}_{8}\right)$ and weedy check $\left(\mathrm{T}_{9}\right)$.

The soil of the experimental field characterized as fairly uniform and leveled. clay loam in texture, having slightly alkaline $\mathrm{pH}$ (7.7), moderate organic carbon status $(0.41 \%)$, low nitrogen content $(197.21 \mathrm{~kg}$ ha ${ }^{1}$ ), medium available phosphorus content $\left(18.76 \mathrm{~kg} \mathrm{ha}^{-1}\right)$ and high available potassium (366.49 $\mathrm{kg} \mathrm{ha}^{-1}$ ). From the very beginning, the field was prepared to obtain a best possible fine tillage for the better survival of young onion seedlings.

Approximately six to seven weeks old onion seedlings of variety "Akola safed" were treated for 10 minutes with a solution of bavistine@0.5gm lit ${ }^{-1}$ of water to protect the crop from the threat of various fungal diseases. Then the seedlings were manually transplanted on $14^{\text {th }}$ December 2018 with a spacing of $20 \mathrm{~cm}$ in between lines and $10 \mathrm{~cm}$ within the line in a plot size of $6.5 \mathrm{~m} \mathrm{x} 5 \mathrm{~m}$ with 100:50:50 NPK $\mathrm{kg} \mathrm{ha}^{-1}$. Soon after transplanting, light irrigation was given for the quick seedling establishment.

The application of herbicide was done as per the treatments with manually operated knapsack sprayer attached with a flood jet nozzle. After calibrating the sprayer, water volume used was 700 lit. per ha. for pre emergence herbicides and 500 lit. per ha. for post emergence herbicides. For hand weeding, weeds were removed manually by using the khurpi with female manpower as per the 
scheduled dates in treatment details. Every possible package of practices was adapted uniformly with an utmost care to raise a highquality crop. Five plants were randomly selected from each replication per treatment for recording the yield attributing traits after harvesting. The crop was harvested on $9^{\text {th }}$ April, 2019.

The observations on weed density and weed biomass were taken at 20 days interval upto harvest from four randomly selected spots by using a quadrate of $50 \mathrm{~cm}$ x $50 \mathrm{~cm}$ quadrate from net plot area. Then weeds were grouped as monocot species and dicot species. Weed control efficiency (WCE) was calculated by using standard formula suggested by Maity and Mukherjee (2011).

Phytotoxicity symptoms due to herbicides on crop was recorded by using a visual score scale of $0-10$ scale method as proposed by Rao (2000).Visual assessment of herbicide toxicity on crop was monitored 10 days after application of herbicide in respective treatment. Data on various yield attributing characters were statistically analysed as per the standard procedure.

\section{Results and Discussion}

\section{Weed flora}

The selected experimental site was a weed prone area with wide diversities of monocot and dicot weeds but dominance of monocot weeds was observed in entire field. Weed flora observed in the experimental field, mainly comprised of Datura stramonium, Parthenium hysterophorus, Euphorbia hirta L., Commelina benghalensis, Alternanathera triandra, Digera arvensis Forst., Tridax procumbens L., Euphorbia geniculata Orteg., Argemone mexicana L., Xanthium strumarium L., Chenopodium album L.,Phyllanthus niruri L., Portulaca oleracea L., Lagasca mollis and
Acalypha indica these were dicot weeds and among monocot Cyprus rotundus, Cynodon dactylon, Eleusin indica L. and Dactyloctenium aegyptium L. Among the different weed species, Datura stramonium was the most dominant weed, while Parthenium hysterophorus was second in weed density and other weeds were followed by them. Similar types of weeds in onion field were also reported by Patel et al., (2011), Kalhapure et al., (2014), Gaharwar et al., (2017) and Thakare et al., (2018).

\section{Effect on weeds}

The data presented in Tables 1 revealed that the weed control treatments significantly reduced the total (monocot + dicot) weed population and total dry weed biomass as compared with unweeded control. Initially at 20 DAT significantly lowest total weeds density and ultimately lowest dry matter was recorded in treatment Pendimethalin 24\% + Oxyfluorfen 4\% ZE @1083.60+185.12 g a.i./ha $\mathrm{PE}\left(\mathrm{T}_{4}\right)$ than rest of the weed management treatments due to its higher concentration but from 40 DAT and onwards its higher concentration restrict plant growth by showing slight retardation in plant growth as compared to other and hence from 40 DAT onwards upto harvest significantly lowest total weeds density and weed dry matter was recorded in the treatment of cultural practice of two hand weeding at 25 and 45 DAT $\left(\mathrm{T}_{8}\right)$ than rest of the weed management treatments.

Lower weed count resulted into lower dry matter. Among herbicidal treatment, Pendimethalin 24\% + Oxyfluorfen 4\% ZE @ 600+102.5 g a.i./ha PE $\left(\mathrm{T}_{3}\right)$ produced lower weed count but were statistically at par with Oxyfluorfen $23.5 \% \quad$ EC@ 200 g a.i./ha $\operatorname{PE}\left(\mathrm{T}_{6}\right)$. The Weedy check $\left(\mathrm{T}_{9}\right)$ treatment recorded significantly higher weed population at all the growth stages during the experimentation. 
From 40 DAT upto harvesting stage, treatment weed free $\left(\mathrm{T}_{8}\right)$ found significantly superior in reducing the total weeds population than rest of the weed management treatments. The combination of pre mixed herbicide Pendimethalin 24\% + Oxyfluorfen 4\% ZE@600+102.5 g a.i./ha PE $\left(\mathrm{T}_{3}\right)$ showed its superiority in lowering down the weed population and dry matter over all other herbicidal treatments. Total weed density and weed dry biomass was reduced significantly due to various weed control treatments at all stages of crop growth.

This might be due to the herbicidal application alone and in combinations which were effective in timely reducing total weed population which result in lower weed dry matter accumulation. Pendimethalin inhibits germination of weed seed and oxyfluorfen disrupt cell membrane by lipid peroxidation. Similar results were reported by Bharathi et al., (2011), Kalhapure et al., (2013) and Gupta et al., (2019).

Weed control efficiency of onion was significantly influenced by weed management treatments, where all the treatments resulted in increase of weed control efficiency over the weedy check. The sequential application of pre and post emergence herbicides was found superior. The highest weed control efficiency was observed in treatment Pendimethalin 24\% + Oxyfluorfen 4\% ZE @1083.60+185.12 g a.i./ha PE $\left(\mathrm{T}_{4}\right)$ at $20 \mathrm{DAT}$ but from $40 \mathrm{DAT}$ up to at harvest, highest WCE was observed in treatment with two HW (25 \& 45 DAT) because of keeping weed free environment and found superior over rest of all herbicidal treatments.

Among the herbicides at harvest ,the highest weed control efficiency $(85.86 \%)$ was found with Pendimethalin 24\% + Oxyfluorfen 4\% ZE @600+102.5 g a.i./ha PE $\left(\mathrm{T}_{3}\right)$ followed by Oxyfluorfen 23.5\% EC@ 200 g a.i./ha PE
$(85.29 \%)\left(\mathrm{T}_{6}\right)$ and Pendimethalin 24\% + Oxyfluorfen 4\% ZE @ 1083.60+185.12 g a.i./ha PE $\left(\mathrm{T}_{4}\right)(84.73 \%)$. This showed that all the pre-emergence and post emergence herbicides used in this experiment were compatible, which increased their efficiency without any phytotoxic effect causing adverse effect on onion.

Data on weed index as indicated in Table 2 showed the least yield reduction $(4.29 \%)$ in treatment with application of Pendimethalin $24 \%$ + Oxyfluorfen 4\% ZE @600+102.5 g a.i./ha $\mathrm{PE}\left(\mathrm{T}_{3}\right)$ followed by the treatments Oxyfluorfen 23.5\% EC@ 200 g a.i./ha PE $(12.25 \%)\left(\mathrm{T}_{6}\right)$ and Pendimethalin $24 \%+$ Oxyfluorfen 4\% ZE @ 1083.60+185.12 g a.i./ha $\mathrm{PE}\left(\mathrm{T}_{4}\right) \quad(14.78 \%)$. Whereas yield reduction varied from $4.29 \%$ to $33.35 \%$ in the herbicide applied plots as compared to weed free treatment.

Weedy check $\left(\mathrm{T}_{9}\right)$ treatment recorded maximum weed index i.e. $54.33 \%$ indicating the reduction in onion bulb yield due to presence of weeds throughout crop growth period. Lower is the weed index in chemical treatments, better the efficiency of that herbicide in controlling weeds, which provided favorable conditions for crop growth which ultimately increased the bulb yield of onion crop as compared to weedy check treatment. This result corroborate with finding of Kolse et al., (2010), Shinde et al., (2012), Jangre et al., (2014) and Sable et al., (2015).

\section{Crop phytotoxicity}

Phytotoxicity symptoms due to herbicide on onion crop was recorded by using visual score scale of $0-10$. Visual assessment of herbicide toxicity on crop was monitored 10 days after application of herbicide in respective treatment. Data presented in Table 2 revealed that none of the herbicides under study shown any phytotoxicity symptoms on crop growth 
during the experimentation only with the exception of treatment $\left(\mathrm{T}_{4}\right)$ pendimethalin 24\% + oxyfluorfen 4\% ZE @ 1083.60+185.12 $\mathrm{g}$ a.i./ha as PE where leaf injury on tips and necrosis observed which was upto the easily recoverable extent was observed. The phytotoxicity was seen initially but the onion plants that were injured were recovered upto harvest. The results are in accordance with the finding of Yadav et al., (2009) and Uygur et al., (2010).

\section{Effect on yield attributing traits}

The data of yield attributing characters presented in Table 3 revealed that, the weed control treatments showed significant influence on average bulb weight, equatorial diameter, polar diameter and total bulb yield which significantly influenced by different herbicidal treatments. Different weed control treatments registered significant increase in all the yield attributing characters compared to unweeded control. The Hand weeding twice i.e. 25 and 45 days after planting produced significantly highest onion bulb yield as compared to other treatments and remain at par with application of Pendimethalin 24\% + Oxyfluorfen $4 \%$ ZE @ 600+102.5 g a.i./ha PE $\left(\mathrm{T}_{3}\right)$.

Significantly maximum values for yield attributing traits were recorded in weed free plots (Two hand weedings) followed by others herbicidal treatments due to the favorable environmental conditions created by the clean crop culture resulted in more absorption of solar radiation and plant nutrients which ultimately resulting in more photosynthetic rates and dry matter accumulation. Among the herbicidal treatments highest yield contributing traits values such as average bulb weight (101.77 g), equatorial and polar diameter (67.64 and 54.01) and total bulb yield (188.29 $\left.\mathrm{qha}^{-1}\right)$ were recorded in treatment with application of
Pendimethalin 24\% + Oxyfluorfen 4\% ZE @600+102.5 g a.i./ha PE $\left(\mathrm{T}_{3}\right)$, which is closely followed by pre emergence application of Oxyfluorfen 23.5\% EC@ $200 \mathrm{~g}$ a.i./ha PE $\left(\mathrm{T}_{6}\right)$ and Pendimethalin $24 \%+$ Oxyfluorfen 4\% ZE @ 1083.60+185.12 g a.i./ha $\left(\mathrm{T}_{4}\right)$ as pre-emergence were significantly at par with each other. The findings are in close proximity to that of Tripathy et al., (2013); Thakare et al., (2018) and Gupta et al., (2019). The lowest yield attributes were recorded in weedy check plots owing to low chlorophyll content and photosynthetic rate due to unchecked weed growth there by reducing the availability of moisture, light and nutrients to the crop thus resulting in loss of yield (Channappagoudar and Biradar, 2007).

\section{Economics}

The data related to cost of cultivation, gross return, net return, benefit:cost ratio under various weed management practices are presented in Table 3. The highest net monetary return of Rs $126870 \mathrm{ha}^{-1}$ was obtained with application of $\left(\mathrm{T}_{3}\right)$ Pendimethalin 24\% + Oxyfluorfen 4\% ZE @600+102.5 g a.i./ha PE with benefit: cost ratio of 3.04. Though weeds were controlled more efficiently and bulb yield production was highest in treatment of two hand weeding at 25 and 45 DAT, its cost of cultivation was also higher (Rs $69870 \mathrm{ha}^{-1}$ ) because of the higher human labour requirement and their higher wages. The cost of human labours for controlling weeds was reduced with application of pre emergence herbicides , which was responsible for reduction in total cost of cultivation, resulting maximum $\mathrm{B}: \mathrm{C}$ in treatment Pendimethalin 24\% + Oxyfluorfen 4\% ZE @600+102.5 g a.i./ha PE $\left(\mathrm{T}_{3}\right)$. Similarly economical parameters of onion in respect of methods of weed control were also studied earlier by Gupta et al., (2019). 
Table.1 Weed density (No./m2) and weed dry matter $(\mathrm{g} / \mathrm{m} 2)$ as influenced by different weed control treatments in onion

\begin{tabular}{|c|c|c|c|c|c|c|c|c|c|c|}
\hline \multirow[t]{2}{*}{ Treatment } & \multicolumn{5}{|c|}{ Total weed density } & \multicolumn{5}{|c|}{ Weed dry matter } \\
\hline & $\begin{array}{c}20 \\
\text { DAT }\end{array}$ & 40 DAT & 60 DAT & 80 DAT & $\begin{array}{c}\text { At } \\
\text { harvest }\end{array}$ & $\begin{array}{c}20 \\
\text { DAT }\end{array}$ & 40 DAT & 60 DAT & $\begin{array}{c}80 \\
\text { DAT }\end{array}$ & $\begin{array}{c}\text { At } \\
\text { harvest }\end{array}$ \\
\hline $\begin{array}{c}\text { T }_{1} \text { - Pendimethalin } 24 \% \text { + Oxyfluorfen } 4 \% \\
\text { ZE @ 480+82 g a.i./ha PE }\end{array}$ & $\begin{array}{c}4.21 \\
(17.23)\end{array}$ & $\begin{array}{c}4.97 \\
(24.20)\end{array}$ & $\begin{array}{c}6.36 \\
(40.40)\end{array}$ & $\begin{array}{c}7.59 \\
(57.67)\end{array}$ & $\begin{array}{c}8.14 \\
(66.23)\end{array}$ & $\begin{array}{c}2.93 \\
(8.08)\end{array}$ & $\begin{array}{c}3.27 \\
(10.31)\end{array}$ & $\begin{array}{c}3.63 \\
(12.69)\end{array}$ & $\begin{array}{c}3.88 \\
(14.70)\end{array}$ & $\begin{array}{c}4.28 \\
(17.93)\end{array}$ \\
\hline $\begin{array}{c}\mathrm{T}_{2} \text { - Pendimethalin } 24 \% \text { + Oxyfluorfen } 4 \% \\
\text { ZE @541.80+92.56 g a.i./ha PE }\end{array}$ & $\begin{array}{c}3.62 \\
(12.90)\end{array}$ & $\begin{array}{c}4.60 \\
(20.63)\end{array}$ & $\begin{array}{c}5.51 \\
(30.13)\end{array}$ & $\begin{array}{c}6.75 \\
(45.11)\end{array}$ & $\begin{array}{c}7.18 \\
(51.03)\end{array}$ & $\begin{array}{c}2.61 \\
(6.52)\end{array}$ & $\begin{array}{c}2.93 \\
(8.13)\end{array}$ & $\begin{array}{c}3.27 \\
(10.30)\end{array}$ & $\begin{array}{c}3.58 \\
(12.37)\end{array}$ & $\begin{array}{c}4.04 \\
(15.83)\end{array}$ \\
\hline $\begin{array}{c}\mathrm{T}_{3} \text { - Pendimethalin } 24 \% \text { + Oxyfluorfen } 4 \% \\
\text { ZE @600+102.5 g a.i./ha PE }\end{array}$ & $\begin{array}{c}3.06 \\
(9.07)\end{array}$ & $\begin{array}{c}4.23 \\
(17.43)\end{array}$ & $\begin{array}{c}4.89 \\
(23.43)\end{array}$ & $\begin{array}{c}5.75 \\
(32.80)\end{array}$ & $\begin{array}{c}6.49 \\
(41.67)\end{array}$ & $\begin{array}{c}2.28 \\
(5.00)\end{array}$ & $\begin{array}{c}2.53 \\
(6.03)\end{array}$ & $\begin{array}{c}2.82 \\
(7.47)\end{array}$ & $\begin{array}{c}3.23 \\
(9.96)\end{array}$ & $\begin{array}{c}3.72 \\
(13.37)\end{array}$ \\
\hline $\begin{array}{c}\mathrm{T}_{4} \text { - Pendimethalin } 24 \% \text { +Oxyfluorfen } 4 \% \\
\text { ZE @1083.60+185.12 g a.i./ha PE }\end{array}$ & $\begin{array}{c}3.03 \\
(8.90)\end{array}$ & $\begin{array}{c}4.38 \\
(19.67)\end{array}$ & $\begin{array}{c}4.99 \\
(24.47)\end{array}$ & $\begin{array}{c}5.92 \\
(34.87)\end{array}$ & $\begin{array}{c}6.64 \\
(43.67)\end{array}$ & $\begin{array}{c}2.22 \\
(4.50)\end{array}$ & $\begin{array}{c}2.58 \\
(6.27)\end{array}$ & $\begin{array}{c}2.84 \\
(7.60)\end{array}$ & $\begin{array}{c}3.27 \\
(10.17)\end{array}$ & $\begin{array}{c}3.85 \\
(14.33)\end{array}$ \\
\hline $\begin{array}{c}\mathrm{T}_{5} \text { - Pendimethalin } 38.7 \% \text { CS@ } 677.25 \mathrm{~g} \\
\text { a.i./ha PE }\end{array}$ & $\begin{array}{c}4.00 \\
(15.50)\end{array}$ & $\begin{array}{c}4.92 \\
(23.70)\end{array}$ & $\begin{array}{c}5.90 \\
(34.67)\end{array}$ & $\begin{array}{c}6.64 \\
(43.70)\end{array}$ & $\begin{array}{c}7.54 \\
(56.33)\end{array}$ & $\begin{array}{c}2.86 \\
(7.70)\end{array}$ & $\begin{array}{c}3.07 \\
(8.94)\end{array}$ & $\begin{array}{c}3.47 \\
(11.51)\end{array}$ & $\begin{array}{c}3.76 \\
(13.64)\end{array}$ & $\begin{array}{c}4.44 \\
(19.23)\end{array}$ \\
\hline $\begin{array}{c}\text { T }_{6}-\text { Oxyfluorfen } 23.5 \% \text { EC@ } 200 \mathrm{~g} \text { a.i./ha } \\
\text { PE }\end{array}$ & $\begin{array}{c}3.37 \\
(10.90)\end{array}$ & $\begin{array}{c}4.39 \\
(18.80)\end{array}$ & $\begin{array}{c}4.96 \\
(24.13)\end{array}$ & $\begin{array}{c}5.91 \\
(34.57)\end{array}$ & $\begin{array}{c}6.61 \\
(43.37)\end{array}$ & $\begin{array}{c}2.35 \\
(5.34)\end{array}$ & $\begin{array}{c}2.57 \\
(6.10)\end{array}$ & $\begin{array}{c}2.85 \\
(7.72)\end{array}$ & $\begin{array}{c}3.24 \\
(10.00)\end{array}$ & $\begin{array}{c}3.75 \\
(13.80)\end{array}$ \\
\hline $\begin{array}{c}\mathrm{T}_{7} \text { - Quizalofop ethyl } 5 \% \text { EC@ } 50 \mathrm{~g} \text { a.i./ha } \\
\text { PoE }\end{array}$ & $\begin{array}{c}7.58 \\
(56.97)\end{array}$ & $\begin{array}{c}7.26 \\
(52.30)\end{array}$ & $\begin{array}{c}8.36 \\
(70.23)\end{array}$ & $\begin{array}{c}9.20 \\
(84.17)\end{array}$ & $\begin{array}{c}10.17 \\
(104.47)\end{array}$ & $\begin{array}{c}4.42 \\
(19.23)\end{array}$ & $\begin{array}{c}3.32 \\
(11.11)\end{array}$ & $\begin{array}{c}3.92 \\
(15.26)\end{array}$ & $\begin{array}{c}4.49 \\
(19.77)\end{array}$ & $\begin{array}{c}5.02 \\
(26.27)\end{array}$ \\
\hline T $_{8-}$ Two HW (25 \& 45 DAT) & $\begin{array}{c}7.45 \\
(55.07)\end{array}$ & $\begin{array}{c}3.43 \\
(11.23)\end{array}$ & $\begin{array}{c}3.86 \\
(14.80)\end{array}$ & $\begin{array}{c}4.35 \\
(18.67)\end{array}$ & $\begin{array}{c}4.81 \\
(22.88)\end{array}$ & $\begin{array}{c}3.98 \\
(15.37)\end{array}$ & $\begin{array}{c}2.26 \\
(4.73)\end{array}$ & $\begin{array}{c}2.80 \\
(7.33)\end{array}$ & $\begin{array}{c}2.98 \\
(8.36)\end{array}$ & $\begin{array}{c}3.35 \\
(10.80)\end{array}$ \\
\hline$T_{9}$-Weedy Check & $\begin{array}{c}7.86 \\
(61.30)\end{array}$ & $\begin{array}{c}13.06 \\
(171.27)\end{array}$ & $\begin{array}{c}15.03 \\
(225.83)\end{array}$ & $\begin{array}{c}16.18 \\
(263.20)\end{array}$ & $\begin{array}{c}17.04 \\
(291.73)\end{array}$ & $\begin{array}{c}6.67 \\
(44.03)\end{array}$ & $\begin{array}{c}7.89 \\
(62.27)\end{array}$ & $\begin{array}{c}8.65 \\
(75.30)\end{array}$ & $\begin{array}{c}9.06 \\
(83.53)\end{array}$ & $\begin{array}{c}9.68 \\
(93.86)\end{array}$ \\
\hline S.E(m) \pm & 0.23 & 0.27 & 0.40 & 0.46 & 0.50 & 0.23 & 0.26 & 0.30 & 0.34 & 0.39 \\
\hline C.D. at $5 \%$ & 0.70 & 0.83 & 1.21 & 1.39 & 1.51 & 0.69 & 0.80 & 0.92 & 1.02 & 1.17 \\
\hline
\end{tabular}

Figures in parenthesis are original value 
Table.2 Crop phytotoxicity score, Weed control efficiency (\%) and weed index (\%) as Influenced by different weed control treatments in onion

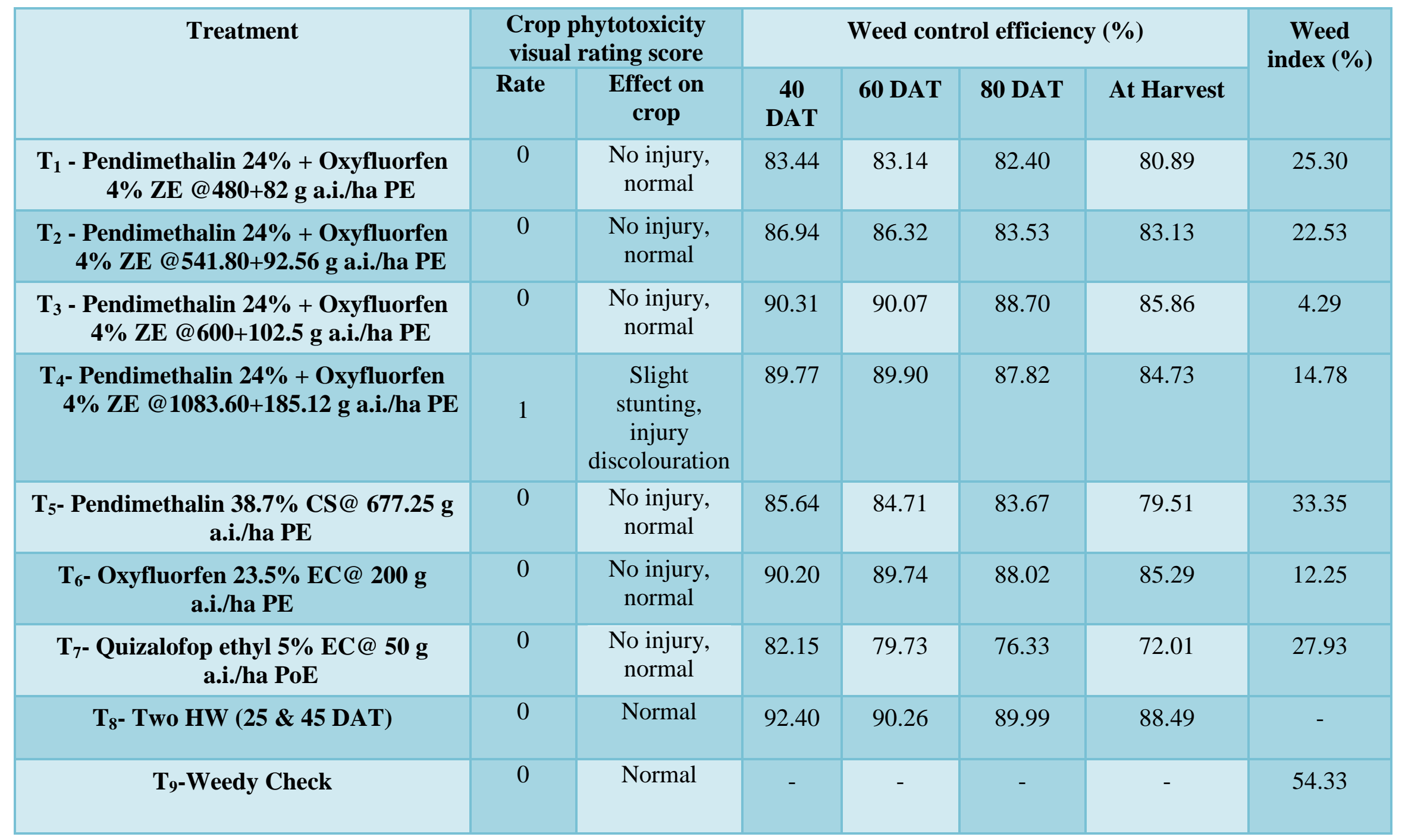


Table.3 Yield attributes and onion bulb yield (q/ha) as influenced by different weed control treatments

\begin{tabular}{|c|c|c|c|c|c|c|c|}
\hline Treatment & $\begin{array}{l}\text { Average } \\
\text { Bulb } \\
\text { weight } \\
\text { (g) }\end{array}$ & $\begin{array}{l}\text { Equatorial } \\
\text { Diameter } \\
(\mathbf{m m})\end{array}$ & $\begin{array}{l}\text { Polar } \\
\text { Diameter } \\
(\mathbf{m m})\end{array}$ & $\begin{array}{l}\text { Total bulb } \\
\text { yield } \\
\text { (q/ha) }\end{array}$ & $\begin{array}{l}\text { Gross } \\
\text { monetary } \\
\text { returns } \\
\left(\text { Rs ha }^{-1}\right)\end{array}$ & $\begin{array}{l}\text { NMR } \\
\left(\text { Rs ha }^{-1}\right)\end{array}$ & $\begin{array}{l}\mathrm{B}: \mathrm{C} \\
\text { ratio }\end{array}$ \\
\hline $\begin{array}{c}\mathrm{T}_{2} \text { - Pendimethalin } 24 \%+ \\
\text { Oxyfluorfen 4\% ZE } \\
\text { @541.80+92.56 g a.i./ha PE }\end{array}$ & 98.50 & 61.69 & 48.69 & 152.40 & 152400 & 90776 & 2.47 \\
\hline $\begin{array}{c}\mathrm{T}_{3} \text { - Pendimethalin } 24 \%+ \\
\text { Oxyfluorfen 4\% ZE @600+102.5 } \\
\text { g a.i./ha PE }\end{array}$ & 101.77 & 67.64 & 54.01 & 188.29 & 188290 & 126870 & 3.04 \\
\hline $\begin{array}{c}\mathrm{T}_{4} \text { - Pendimethalin } 24 \%+ \\
\text { Oxyfluorfen 4\% } \mathrm{ZE} \\
\text { @1083.60+185.12 g a.i./ha PE }\end{array}$ & 91.60 & 64.49 & 50.92 & 167.66 & 167660 & 103142 & 2.59 \\
\hline $\begin{array}{c}\text { T }_{7} \text { Quizalofop ethyl 5\% EC@ } 50 \text { g } \\
\text { a.i./ha PoE }\end{array}$ & 75.37 & 54.18 & 44.44 & 141.79 & 141791 & 80371 & 2.30 \\
\hline T $_{8^{-}}$Two HW (25 \& 45 DAT) & 107.60 & 68.06 & 56.30 & 196.74 & 196740 & 126520 & 2.81 \\
\hline T9-Weedy Check $_{9}$ & 60.03 & 49.84 & 40.57 & 89.84 & 89740 & 29950 & 1.50 \\
\hline S.E(m) \pm & 4.45 & 3.51 & 2.71 & 9.42 & 6869 & 6869 & - \\
\hline C.D. at $5 \%$ & 13.34 & 10.52 & 8.12 & 28.25 & 20595 & 20595 & - \\
\hline
\end{tabular}


It was concluded that application of pre emergence herbicides Pendimethalin 24\% + Oxyfluorfen 4\% ZE @600+102.5 g a.i./ha PE found to be suitable and economical herbicide in onion. The conventional cultural method of weed control is effective, however due to labour scarcity and high cost of human labour weeding during the critical stage of the crop is a problem. As an alternative option, pre-mix herbicide application as a pre-emergence method of weed control can be the good option for management of weeds in onion.

\section{References}

Anonymous 2017. National Horticultural Research and Development Foundation Nashik, Maharashtra 422201.

Bharathi, S., Rao A S. and Surya KumariS., 2011. Effect of weed management practices on weed control and yield of onion (Alium cepa L) in vertisols.J.Res. ANGRAU 39(1\&2)10-13.

Channapagoudar, BB. And Biradar NR., 2007. Physiological studies on weed control efficiency in direct sown onion. Karnataka J. Agric. Sci. 20.(2):375-376.

Gaharwar AM., Patil N.,\& Ughade J.,2017. Effect of integrated weed management on growth, yield and economic returns on onion (Alium cepa L.) Asian j. Hort., 12 (2) : 193-197.

Gupta N., Bhargav KS.and Singh M., 2019.Effect of Integrated Weed Management on Growth and Yield of Kharif Onion (Allium cepa).J Krishi Vigyan 2019, 7 (2) : 83-87.

Ibrahim, U., Oluwatosin OJ., Ayinde BT. and MahmoudBA., 2011. Evaluation of Herbicides on Weed Control, Performance and Profitability of Onion (Allium cepa) in the Forest Zone of Nigeria.Middle-East J. Scientific Res. 9 (5): 611-615.

Jangre, N., Gupta CR., Mehta N., and Soni AK., 2014. Efficacy of pre and post- emergence herbicides on plant growth, weed density and yield of onion in Chhattisgarh plains. Green farming 5 (2): 289-291.

Kalhapure, AH. and Shete BT., 2013. Effect of weed management practices on weed dynamics, weed control efficiency, bulb yield and economics in onion. J. Agric. Res. Technol., 38 (2) : 238-240.

Kalhapure, AH., Shete BT. and Dhonde M., 2014. Weed management in onion (Allium cepa L.) by pre-planting and post-emergence herbicides for seed production. Indian Journal of Weed Sciences 46 (2): 142-145.

Kolse, RH., Gaikwad CB., Jadhav JD.and Yadav ST., 2010. Efficiency of chemical weed control methods in onion seed production for controlling weeds and its effect on yield. International J. Plant Protection Vol. 3 No. 1: 55-59.

Maity SK. and Mukherjee PK.,2011.Effect of brown manuring on grain yield and nutrient use efficiency in dry direct seeded kharif rice.Indian Journal of Weed Science 43: 61-66.

Patel, TU., Patel CL., Patel DD., Thanki JD., Patel PS., and Jat RA., 2011.Effect of weed and fertilizer management on weed control and productivity of onion (Allium cepa L.). Indian Journal of Agronomy 56 (3): 267-272.

Rao,VS., 2000. Principles of weed science II $^{\text {nd }}$ Edn.Oxford and IBH publishing Co., New Delhi.

Sable PA., Purane AB. and Jadhav SN., (2015). Studies on integrated weed management in onion.BIOINFOLET- A quarterly journal of life sciences., 11 (2): 627-631.

Shinde, KG., Bhalekar MN.and Patil BT., 2012. Weed management in rainy season onion. Indian J. Weed Sci. 44(4): 264-266.

Thakare S., Chirde PN., Deshmukh JP., 
Kakade SU., Shingrup PV., Gholap AN., 2018. Weed Management in onion by pre and post emergence Herbicide. ISSN2319-7692 special issue $6 \mathrm{pp}$ 2197-2202.

Uygur, S.,Gurbuz R.and Nezihi Uygur F. Weeds of onion fields and effects of some herbicides on weeds in Cukurova region, Turkey, 2010. African Journal of Biotechnology Vol. 9(42), pp. 70377042 .
Vishnu, V., Asodariya, KB.,Suthar, A. and Meena, DK. 2014. Effect of herbicides on phytotoxicity and weed reduction in rabi Onion (Allium cepa L.) Trends in Bioscience 7(23): 4011-4015.

Yadav, AC., Punia SS., Telhan S. and Singh A. 2009. Performance of different herbicides in onion as affected by method of application. Indian Journal of Weed Science 41(3\&4): 193- 1942009.

\section{How to cite this article:}

Akanksha Thakare, S. U. Kakade, J. P. Deshmukh, N. D. Parlawar and S. S. Thakare. 2020. Efficacy of Pre and Post Emergence Herbicides against Weed Flora in Onion (Allium cepa L.). Int.J.Curr.Microbiol.App.Sci. 9(07): 301-310. doi: https://doi.org/10.20546/ijcmas.2020.907.032 